\title{
ACMENA, ACMENOSPERMA, CLEISTOCALYX, PILIOCALYX AND WATERHOUSEA FORMALLY TRANSFERRED TO SYZYGIUM (MYRTACEAE)
}

\author{
L.A. CRAVEN 1 , E. BIFFIN ${ }^{1,2}$ \& P.S. ASHTON 3
}

\begin{abstract}
SUMMARY
Based on morphological and molecular data, we have concluded that Acmena, Acmenosperma, Cleistocalyx, Piliocalyx and Waterhousea should be combined with Syzygium. The five genera are formally transferred to Syzygium and new names provided for those of their accepted representatives for which names are as yet not available in Syzygium, with the exception of the New Caledonian members of Piliocalyx as these currently are being revised.
\end{abstract}

Key words: Myrtaceae, Acmena, Acmenosperma, Cleistocalyx, Piliocalyx, Syzygium, Waterhousea, taxonomy.

\section{INTRODUCTION}

The myrtle flora of the Old World rain forests is dominated by Syzygium Gaertn. and its generic allies. Current estimates are that these genera, Acmena DC., Acmenosperma Kausel, Cleistocalyx Blume, Piliocalyx Brongn. \& Gris, Syzygium Gaertn. and Waterhousea $\mathrm{B}$. Hyland, together contain in the order of 1200 species. In habit, they range from canopy-emergent trees to canopy trees, understorey trees, treelets and shrubs, and occur from littoral communities at sea level through swamp forests, lowland and montane forests to subalpine shrubberies. They have high ecosystem significance as their (often massed) nectariferous flowers and (usually) fleshy fruit are food sources for a wide range of animals, from small insects through to cassowaries and primates. Several species, e.g. S. aqueum (Burm.f.) Alston, S. cumini (L.) Skeels and S. malaccense (L.) Merr. \& L.M. Perry are widely cultivated, especially in the Malesian region, for their edible fruit, and one species, S. aromaticum (L.) Merr. \& L.M. Perry, is extensively cultivated for its flower buds that are dried and used as the spice, clove. In some areas, especially New Guinea, species of the group can form a significant proportion of the logs extracted during forestry operations although the timber is not highly valued for cabinet or veneer work and is utilised for general purpose construction and as a filler in laminated boards.

1) Australian National Herbarium, CPBR, CSIRO Plant Industry, G.P.O. Box 1600, Canberra, ACT 2601, Australia.

2) Division of Botany and Zoology, Australian National University, Canberra, ACT 0200, Australia.

3) Harvard University Herbaria, 22 Divinity Avenue, Cambridge MA 01238, USA; Royal Botanic Gardens Kew, Richmond, Surrey, TW9 3AB, United Kingdom. 
The basis for floristic work on the Syzygium generic group within the Indo-Pacific region during the past 50 years has been the taxonomic studies by E.D. Merrill and/or L.M. Perry (references given in Schmid, 1972a, and in Craven, 2001). The generic concepts of Merrill \& Perry were adopted by the majority of taxonomists with the notable exceptions of Henderson (1949), Kochummen (1978) and some others who continued to treat all species within Eugenia L. as that genus had been circumscribed by Bentham \& Hooker (1865). Merrill \& Perry's concepts largely are congruent with those of Niedenzu (1893) and Diels (1922) in that the Old World species of the Syzygium alliance generically were separate from the Eugenia generic alliance. Schmid's research into generic delimitation of the Eugenia-Syzygium complex indicated that, while Eugenia and the Syzygium group were well distinct, there was little support for maintenance of the several generic segregates from Syzygium (Schmid, 1972a, b). The diagnostic features of Acmena, Acmenosperma, Cleistocalyx, Piliocalyx, Syzygium and Waterhousea are given in tabular form in Craven (2001: Table 1).

The very large number of species of the Syzygium generic complex, coupled with a geographic range from Africa eastwards to the Hawaiian Islands and from Indiasouthern China southwards to southern Australia-New Zealand, makes monography decidedly difficult. It is not surprising that species level systematic work has been restricted to floristic/revisionary accounts or checklists for local regions, e.g. Merrill \& Perry (1939) for Borneo, Merrill (1951) for the Philippines, Henderson (1949) for Malaya, Hartley \& Craven (1977) and Hartley \& Perry (1973) for Papuasia, Ashton (1981) and Kostermans (1981) for Sri Lanka, Hyland (1983) and Craven \& Matarczyk (in press) for Australia, Smith (1985) for Fiji, Chantaranothai \& Parnell $(1993,1994)$ for Thailand, Turner (1997a, b) for Malaya, and Dawson (1999) for New Caledonia. Unfortunately, the generic circumscriptions adopted by these authors often lack consistency. For example, Merrill \& Perry $(1937,1938,1939)$ and Merrill (1951) recognised Acmena, Cleistocalyx and Syzygium, whereas Henderson (1949) combined all under Eugenia; Hyland (1983) recognised Acmena, Acmenosperma, Syzygium (incl. Cleistocalyx) and the Australian endemic Waterhousea, whereas Chantaranothai \& Parnell (1993, 1994) recognised Acmena, Cleistocalyx and Syzygium (incl. Acmenosperma). Turner (1997a) preferred to recognise Syzygium only (incl. Acmena, Acmenosperma, Cleistocalyx) although, in a checklist for Malaya (Turner, 1997b), he recognised the genera then accepted by the Kew Herbarium for the syzygioid species of Malaya, i.e., Acmena, Cleistocalyx, Stereocaryum Burret, Syzygium. Smith (1985) treated the Fijian species of the group under Cleistocalyx, Piliocalyx and Syzygium. The situation is unsatisfactory as there would seem to be as much justification for recognition of Cleistocalyx as there is for Acmenosperma; yet Hyland (1983) did not accept the former while accepting the latter and Chantaranothai \& Parnell $(1993,1994)$ did the opposite. After studying the morphological variation evident in syzygioid species in the Papuasian-Australian-New Caledonian region, Craven (1998, 2001, 2003) considered that only a single large genus, i.e. Syzygium, should be recognised.

The species of the various syzygioid genera, especially within a local region, are generally clear and easy to distinguish. It is higher in the classification that problems arise as attempts are made to inter-relate the species groups and/or to classify them on the basis of features such as presence/absence of a calyptra, stamen number, anther sac orientation, and the presence of intercotyledonary tissue in the seed. Systematists 
have increasingly been taking advantage of the opportunities provided by analysis of molecular sequence data to gain fresh perspectives on the phylogenetic relationships between the groups of species of their particular interest and the evolution and distribution of morphological traits. Phylogenies inferred from molecular sequence data have now been obtained for comprehensive samplings of the Syzygium group of genera (Harrington \& Gadek, 2004, ITS and ETS regions of nuclear ribosomal DNA; Biffin et al., in press a, in press b, matK, $n d h F$ and $r p l 16$ regions of chloroplast DNA). These provide support for the view that the conventionally accepted genera of the Syzygium group are not robust and that homoplasy exists in conventional characters. In particular, the occurrence of calyptra, the sole defining character for Cleistocalyx, is widely distributed across the Syzygium group (Fig. 1). That Cleistocalyx is not a monophyletic group is supported also by numerical and phylogenetic analysis of morphological data. Parnell (1999) analysed morphological data obtained from Thai species of Acmena, Cleistocalyx and Syzygium. Even with such a geographically restricted sampling of species, Cleistocalyx was not demonstrated by phylogenetic analysis to be monophyletic and in the numerical analysis its species did not form a cohesive grouping separate from the Syzygium species.

The distribution of other characters used in the definition of genera similarly are not reflective of monophyly in higher level species groupings (Biffin et al., in press b). Developmental studies indicate that the intercotyledonary tissues, that are such a distinctive feature in the seeds of Acmena, Piliocalyx and Waterhousea, may be homologous with tissues that surround the cotyledons in many Syzygium species and the situation with respect to the condition in Acmenosperma is also being investigated (Biffin, unpublished data). The distribution of intercotyledonary tissues is indicated in Fig. 1.

Our conclusions are that Acmena, Acmenosperma, Piliocalyx and Waterhousea are better included in Syzygium than being maintained as distinct genera. Even if Acmena and Piliocalyx were to be merged, the resultant grouping is still nested within Syzygium. That monophyletic groupings equating to the generic concepts of Piliocalyx and Waterhousea occur at a low topological level in a cladogram is not in itself an argument for the continued taxonomic recognition of these groups at the rank of genus. There are other equally strongly supported monophyletic groupings that similarly could be argued as warranting generic recognition, e.g. the three Fijian Cleistocalyx species (C. decussatus A.C. Sm., C. longiflorus (A.C. Sm.) Merr. \& L.M. Perry and C. ellipticus (A.C. Sm.) Merr. \& L.M. Perry) and the tri-merous New Caledonian Syzygium species (S. auriculatum Brongn. \& Gris, S. lateriflorum Brongn. \& Gris and S. tenuiflorum Brongn. \& Gris). The morphological markers available to characterise these monophyletic groups are few in number and may not hold up across the whole complex, in which case unambiguous taxonomic circumscription would not be possible. Should classification proceed in this direction, the end result would be the establishment of a very large number of finely delimited genera and a residue of species that would be difficult to fit into any of the microgenera. Two botanical dicta are worth mentioning in this context: 1) genera are evolutionary units and consequently exhibit variation, i.e. the concept of patio ludens applies; and 2) the ability to distinguish associations of species does not lead to an automatic conclusion that they should be given taxonomic recognition. 


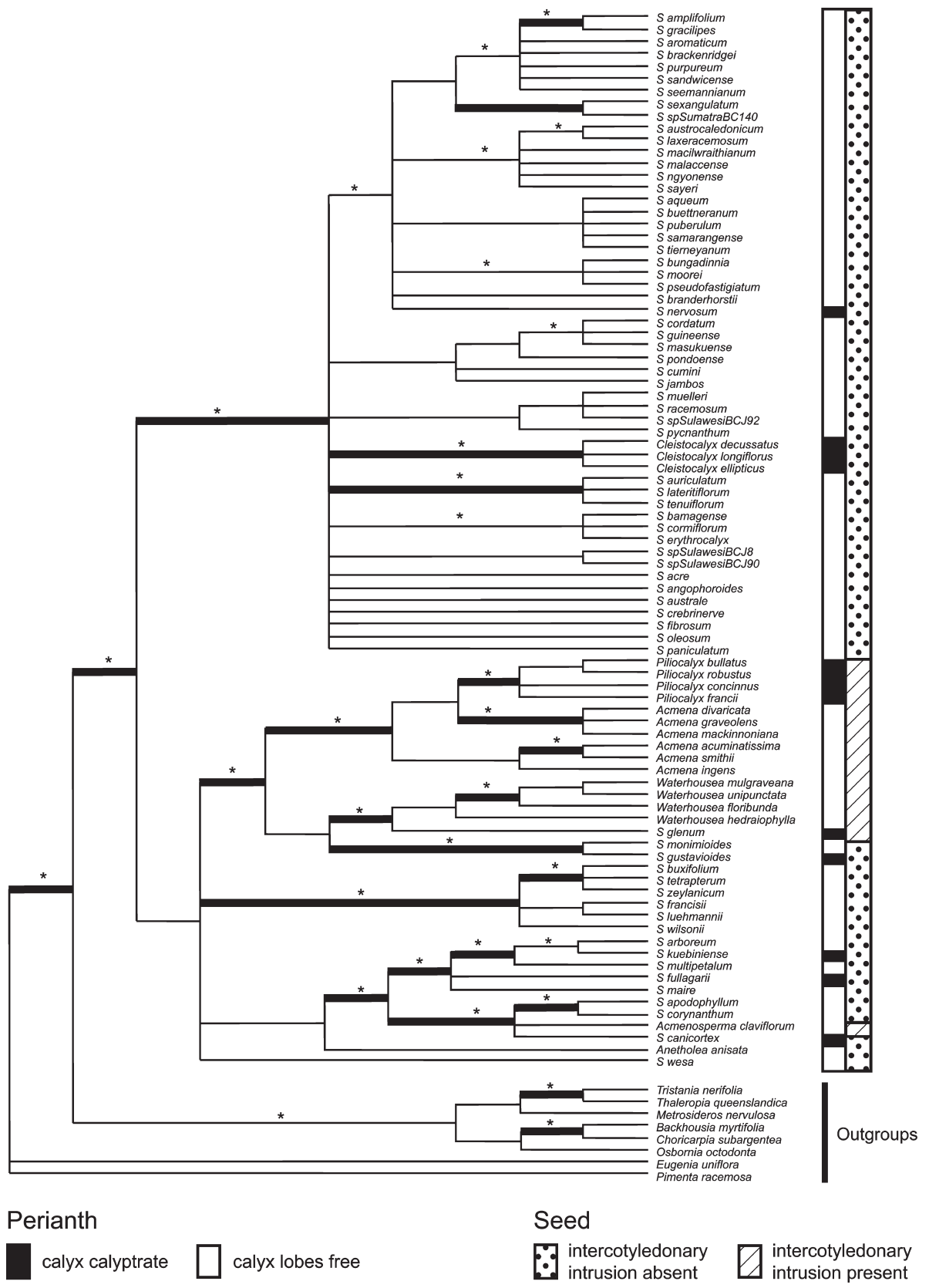

Fig. 1. Distribution of morphological features in the Syzygium group. The cladogram is a strict consensus tree of 1000 most parsimonious trees found in analysis of a combined chloroplast data set (matK, ndhF and $r p l 16$ ). Bold branches represent those receiving $90 \%$ or greater bootstrap support, and asterisks indicate branches with Bayesian posterior probability of $95 \%$ or greater. Based on Biffin et al. (in press b). 
Valid names already exist in Syzygium for several species of the genera concerned, i.e. in some species of Acmena, Acmenosperma, Cleistocalyx and Waterhousea, and names are provided below for most of those species not yet transferred. The exceptions are the New Caledonian species of Piliocalyx. J.W. Dawson, Wellington, presently is revising the New Caledonian representatives of Piliocalyx for 'Flore de la NouvelleCalédonie' (Dawson, pers. comm.) and it would be premature to make new combinations before the species level taxonomy is settled. Syzygium, even without the addition of the relatively small number of species involved in the present recircumscription, is extremely speciose and devising an infrageneric classification will be a priority once current studies into embryology and fruit development are concluded.

Unless indicated by '!', the specimens cited below have not been seen.

\section{SYZYGIUM}

Syzygium Gaertn. (1788) 166, nom. cons. - Type: Syzygium caryophyllaeum Gaertn. (typ. cons.). Acmena DC. (1828) 262. - Type: Acmena smithii (Poir.) Merr. \& L.M. Perry (Eugenia elliptica Sm., nom. illeg., non Lam. (1789) 206).

Acmenosperma Kausel (1957) 609. - Type: Acmenosperma claviflorum (Roxb.) Kausel (Eugenia claviflora Roxb.).

Cleistocalyx Blume (1850) 84. - Type (fide Merrill \& Perry (1937) 333): Cleistocalyx nitidus Blume (Syzygium cleistocalyx (Merr.) P.S. Ashton).

Piliocalyx Brongn. \& Gris (1865) 185, nom. cons. - Type (fide Mansfeld (1935) 449): Piliocalyx robustus Brongn. \& Gris.

Waterhousea B. Hyland (1983) 138. - Type: Waterhousea floribunda (F. Muell.) B. Hyland (Syzygium floribundum F. Muell.).

\section{Syzygium arcuatinervium (Merr.) Craven \& Biffin, comb. nov.}

Basionym: Eugenia arcuatinervia Merr. (1906) 104. - Cleistocalyx arcuatinervius (Merr.) Merr. \& L.M. Perry (1937) 333. - Type: Meyer 2598 (holo PNH†), Philippines, Luzon, Manila Bay area, Lamao Forest Reserve, forests at c. $600 \mathrm{~m}$.

Note - A leaf rubbing made by Merrill of Meyer 2598, presumably from the holotype, is at A (Emily Wood, pers. comm.; xerox seen). The rubbing is accompanied by a leaf of Cuming 1275 which, along with Cuming 1325 and Cuming 1710, represents the same species (fide Merrill, in herb. sched. at A). An isotype of Meyer 2598 is not at $\mathrm{K}$ and a search needs to be made in other herbaria in the effort to locate duplicate material. Failing the existence of such material, it would be possible to lectotypify the name Eugenia arcuatinervia Merr. with the leaf rubbing at A (on the basis that this constitutes part of the original materials used by the author), and designate another gathering as the iconotype. For the latter purpose, Cuming 1275, 1325 and 1710 may be worthy of consideration given that Merrill identified them as representing the species in question.

2. Syzygium baeuerlenii (F. Muell.) Craven \& Biffin, comb. nov.

Basionym: Eugenia baeuerlenii F. Muell. (1886) 199. - Cleistocalyx baeuerlenii (F. Muell.) Merr. \& L.M. Perry (1937) 331. - Type (fide Merrill \& Perry (1937) 332): Baeuerlen s.n. (holo MEL), New Guinea, Papua New Guinea, Western Division, Strickland River. 


\section{Syzygium calyptrocalyx P.S. Ashton, nom. nov.}

Replaced synonym: Cleistocalyx leucocladus Merr. \& L.M. Perry (1937) 336, t. 215, f. 39, 40. - Type: Haviland \& Hose 3382 A, E, L, M (holo GH; iso BO, K, L), Borneo, Sarawak, near Kuching.

Note - A new epithet is required as leucocladum is pre-empted in Syzygium by S. leucocladum Merr. \& L. M. Perry. The replacement epithet is derived from the Greek kalyptos, covered and kalyx, calyx in reference to the floral calyptra.

\section{Syzygium circumscissum (Gagnep.) Craven \& Biffin, comb. nov.}

Basionym: Eugenia circumscissa Gagnep. (1918) 321. - Cleistocalyx circumcissa (Gagnep.) P.H. Hô (1992) 63. - Type: Pierre 6279 (holo P), Cochinchina, Bien-hoa Province, Chiao-xhan Mountains.

Note - The combination Cleistocalyx circumcissa apparently is invalid as Hô (1992) cites the reference Gagnepain, Flore Générale de l'Indochine 2 (1920-1921) 841 but not the protologue. In Article 33.3 of the ICBN (Greuter et al., 2000), for a new combination to be validly published it is stated that to the basionym or replaced synonym there must be a "full and direct reference given to its author and place of valid publication".

\section{Syzygium cleistocalyx (Merr.) P. S. Ashton, comb. nov.}

Basionym: Jambosa nitida Korth. (1847) 202. - Cleistocalyx nitidus Blume (1850) 84, f. 56.

- Eugenia cleistocalyx Merr. (1918) 98. - Type: Korthals s.n. (holo L), Borneo, Kalimantan, Banjarmasin, Mount Bahay.

Note - The epithet cleistocalyx must be used as nitidum is pre-empted in Syzygium by S. nitidum Brongn. \& Gris.

\section{Syzygium concinnum (A.C. Sm.) Craven \& Biffin, comb. nov.}

Basionym: Piliocalyx concinnus A.C. Sm. (1971) 496. - Type: Smith 6155 (holo A; iso BISH, K!, US), Fiji, Viti Levu, Mba Province, hills between Nandala and Nukunuku Creeks, along trail from Nandarivatau towards Lewa.

Note - The name Syzygium concinnum Wall. (Wallich \& Bentham, 1831) is a nomen nudum and the entity concerned, based on 'Wallich's Catalogue 3582', may be referable to S. syzygioides (Miq.) Merr. \& L.M. Perry rather than to S. cymosum (Lam.) DC. as was done by De Candolle (1828).

7. Syzygium conspersipunctatum (Merr. \& L.M. Perry) Craven \& Biffin, comb. nov. Basionym: Cleistocalyx conspersipunctatus Merr. \& L.M. Perry (1937) 335, t. 215, f. 34-36. - Type: How 73332 (holo A), China, Hainan, Po-ting.

8. Syzygium dispansum (Ridl.) Craven \& Biffin, comb. nov.

Basionym: Eugenia dispansa Ridl. (1916) 47. - Acmena dispansa (Ridl.) Merr. \& L.M. Perry (1938) 18. - Type: Kloss (Wollaston Expedition) s.n. (holo BM!), New Guinea, Irian Jaya (Papua), southern slopes of Nassau Range, near Tsingarong River, Camp VIa and Camp VIc, 1912-1913. 
9. Syzygium divaricatum (Merr. \& L.M. Perry) Craven \& Biffin, comb. nov.

Basionym: Acmena divaricata Merr. \& L.M. Perry (1938) 17. - Type: Kajewski 1479 (holo A; iso BRI, MEL!, NSW!, NY), Australia, Queensland, Daintree River.

10. Syzygium fluvicola (Hartley \& Craven) Craven \& Biffin, comb. nov.

Basionym: Acmena fluvicola Hartley \& Craven (1977) 336, f. 2. - Type: Brass 28857 (holo CANB!), New Guinea, Papua New Guinea, Milne Bay Province, Dawa Dawa River, along floodbank, $10 \mathrm{~m}$.

11. Syzygium graveolens (F. M. Bailey) Craven \& Biffin, comb. nov.

Basionym: Cryptocarya graveolens F.M. Bailey (1891) 16. - Acmena graveolens (F.M. Bailey) L.S. Sm. (1956) 34. - Type (fide Hyland (1983) 11): Bailey s.n. (lecto BRI; isolecto MEL!), Queensland, Tringilburra Creek.

12. Syzygium hedraiophyllum (F. Muell.) Craven \& Biffin, comb. nov.

Basionym: Eugenia hedraiophylla F. Muell. (1892) 198. - Waterhousea hedraiophylla (F. Muell.) B. Hyland (1983) 141. - Type (fide Hyland (1983) 141): Sayer s.n. (lecto MEL!; isolecto MEL!), Queensland, Mossman River.

13. Syzygium hemilamprum (F. Muell. ex F.M. Bailey) Craven \& Biffin, comb. nov.

Basionym: Eugenia hemilampra F. Muell. ex F.M. Bailey (1886) 23. - Acmena hemilampra (F. Muell. ex F.M. Bailey) Merr. \& L.M. Perry (1938) 15. - Type (fide Hyland (1983) 12): Dallachy s.n. (lecto MEL!), Queensland, Saltwater Creek.

14. Syzygium hemilamprum (F. Muell. ex F.M. Bailey) Craven \& Biffin subsp. orophilum (B. Hyland) Craven \& Biffin, comb. nov.

Basionym: Acmena hemilampra (F. Muell. ex F.M. Bailey) Merr. \& L.M. Perry subsp. orophila B. Hyland (1983) 13, f. 5. - Type: Hyland 3146 (holo QRS; iso CANB!, MEL!, NSW!), Queensland, State Forest Reserve, 143 North Mary Logging Area.

15. Syzygium ingens (F. Muell. ex C. Moore) Craven \& Biffin, comb. nov.

Basionym: Nelitris ingens F. Muell. ex C. Moore (1861) 48. - Acmena ingens (F. Muell. ex C. Moore) Guymer \& B. Hyland (1988) 437. - Type: C. Moore 19 (holo MEL!; iso K), New South Wales, Richmond River.

16. Syzygium khaoyaiense (Chantar. \& J. Parn.) Craven \& Biffin, comb. nov.

Basionym: Cleistocalyx khaoyaiensis Chantar. \& J. Parn. (1993) 590. - Type: Larsen 10316 (holo C), Thailand, Prachinburi, Khao Yai, Hao Sai Falls.

17. Syzygium lenbrassii Craven \& Biffin, nom. nov.

Replaced synonym: Acmena brassii Craven (1990) 727, f. 1. - Type: Brass 30452 (CANB!), New Guinea, Papua New Guinea, Eastern Highlands region, Mt Wilhelm, east slopes, 2770 m. 
Note - The replacement epithet has been arbitrarily formed from the familiar and family names of the collector, Len Brass (Leonard J. Brass, 1900-1971), as the epithet brassii is pre-empted in Syzygium by S. brassii Merr. \& L.M. Perry.

18. Syzygium mackinnonianum (B. Hyland) Craven \& Biffin, comb. nov.

Basionym: Acmena mackinnoniana B. Hyland (1983) 14, f. 5. - Type: Hyland 3307 RFK (holo QRS; iso CANB!, NSW!), Queensland, Timber Reserve 14.

19. Syzygium melanostictum (Miq.) Craven \& Biffin, comb. nov.

Basionym: Jambosa melanosticta Miq. (1855) 432. - Eugenia melanosticta (Miq.) Koord. \& Valeton (1900) 159. - Acmena melanosticta (Miq.) Merr. \& L.M. Perry (1938) 12. - Type: Junghuhn s.n. (syn. A fragm., U), Java, Pengalengan Plateau.

20. Syzygium mulgraveanum (B. Hyland) Craven \& Biffin, comb. nov.

Basionym: Waterhousea mulgraveana B. Hyland (1983) 143, f. 47. - Type: Dockrill 1295 (holo QRS; iso CANB!, MEL!, NSW!), Queensland, State Forest Reserve 675, East Mulgrave Logging Area.

21. Syzygium nervosum DC. var. paniala (Roxb.) Craven \& Biffin, comb. nov.

Basionym: Eugenia paniala Roxb. (1832) 489. - Eugenia operculata Roxb. var. paniala (Roxb.) Duthie (1879) 498. - Cleistocalyx operculatus (Roxb.) Merr. \& L.M. Perry var. paniala (Roxb.) Chantar. \& J. Parn. (1993) 591. - Cleistocalyx nervosum (DC.) Kosterm. var. paniala (Roxb.) J. Parn. \& Chantar. (1996) 201. - Cleistocalyx cerasoides (Roxb.) I.M. Turner var. paniala (Roxb.) I. M. Turner, in Turner \& Gandhi (2005) 26. - Type: Ic. Roxburgh no. 2255 (K).

22. Syzygium nigrans (Gagnep.) Craven \& Biffin, comb. nov.

Basionym: Eugenia nigrans Gagnep. (1918) 329. - Cleistocalyx nigrans (Gagnep.) Merr. \& L.M. Perry (1937) 336. - Type (fide Merrill \& Perry (1937) 337): Pierre 1934 (holo P; iso A fragm.), Indo-China, Caï-cong, Ongien.

23. Syzygium phengklaii (Chantar. \& J. Parn.) Craven \& Biffin, comb. nov.

Basionym: Cleistocalyx phengklaii Chantar. \& J. Parn. (1993) 591. - Type: Phengklai 4020 (holo PSU; iso A), Thailand, Ratchaburi, Suan Phueng District.

\section{Syzygium piluliferum Craven \& Biffin, nom. nov.}

Replaced synonym: Acmena caudata Merr. \& L.M. Perry (1938) 11. - Type: Endert 3922 (holo BO), Borneo, Kalimantan, Western Koetai, near Kemoel.

Note - A new epithet is required as caudatum is pre-empted in Syzygium by S. caudatum (Merr.) Airy Shaw. The replacement epithet is derived from the diminutive of the Latin pilus, hair, in reference to the puberulous branchlets and inflorescence that were noted by Merrill \& Perry (1938) to be diagnostic. 
25. Syzygium pringlei (B. Hyland) Craven \& Biffin, comb. nov.

Basionym: Acmenosperma pringlei B. Hyland (1983) 26, f. 9. - Type: Hyland 3245 RFK (holo QRS; iso CANB!, MEL!, NSW!), Queensland, Melville Range, Bathurst Bay.

\section{Syzygium pseudocalcicola Craven \& Biffin, nom. nov.}

Replaced synonym: Eugenia paucipunctata Merr. (1915) 215, nom. illeg., non Koord. \& Valeton (1899) 8. - Cleistocalyx paucipunctatus Merr. \& L. M. Perry (1937) 336, t. 215, f. 22, 23 - - Type (neotype designated here): Merrill (Philip. Pl. 1709) (neo GH; iso L), Philippines, Luzon, Benguet Subprovince, near Baguio.

Notes - 1. A new epithet is required as paucipunctatum is pre-empted in Syzygium by $S$. paucipunctatum (Koord. \& Valeton) Merr. \& L. M. Perry. The replacement epithet is derived from the Greek pseudes, false, and the epithet calcicola. Merrill \& Perry (1937) considered this species resembled S. calcicola (Merr.) Merr. in habit.

2. The holotype in PNH was lost with the destruction of the Philippines National Herbarium during World War II. An image of the isotype specimen deposited in GH has been seen and, as the material is adequate and quite ample, the GH specimen is designated above as the neotype.

27. Syzygium resa (B. Hyland) Craven \& Biffin, comb. nov.

Basionym: Acmena resa B. Hyland (1983) 16, f. 6. - Type: Hyland 5760 (holo QRS; iso CANB!, MEL!, NSW!), Queensland, near National Park Reserve 353, Mt Hypipamee.

28. Syzygium retinervium (Merr. \& L.M. Perry) Craven \& Biffin, comb. nov.

Basionym: Cleistocalyx retinervius Merr. \& L.M. Perry (1937) 334, t. 215, f. 12-15. - Type: Clemens 3777 (holo A; iso NY, US), Indo-China, Annam, Tourane and vicinity.

29. Syzygium sorongense (Hartley \& Craven) Craven \& Biffin, comb. nov.

Basionym: Acmena sorongensis Hartley \& Craven (1977) 339. - Type: Van Royen 3195 (CANB!), New Guinea, Irian Jaya (Papua), Vogelkop Peninsula, Klabala River, SE of Sorong.

30. Syzygium unipunctatum (B. Hyland) Craven \& Biffin, comb. nov.

Basionym: Waterhousea unipunctata B. Hyland (1983) 145, f. 48. - Type: Moriarty 1945 (holo QRS; iso CANB!, MEL!, NSW!), Queensland, State Forest Reserve 143, Little Mossman Logging Area.

\section{Syzygium zhenghei Craven \& Biffin, nom. nov.}

Replaced synonym: Acmena montana Hartley \& Craven (1977) 338. - Type: Streimann \& Stevens LAE 53863 (holo CANB!), New Guinea, Papua New Guinea, Morobe Province, vicinity of Aseki.

Note - A new epithet is required as montanum is pre-empted in Syzygium by

S. montanum Thwaites. The arbitrarily formed replacement epithet commemorates 
Zheng He (Cheng Ho, 1371-1435), the senior admiral of the Chinese emperor Zhu Di (1360-1424). Zheng He directed the major fleets of exploration and trade that investigated the world between 1421 and c. 1423. These inspirational voyages have been documented by Menzies (2003) as far as evidence permits.

\section{ACKNOWLEDGEMENTS}

The environment agencies of Provinces Nord and Sud, New Caledonia, are thanked by LAC and EB for the opportunity to observe and collect Myrtaceae for our research, as are Drs Tanguy Jaffré and Jérôme Munzinger, IRD, for facilitating our use of facilities at the Nouméa Herbarium. John Dawson, Wellington, and John Parnell, Dublin, are thanked by LAC for their discussions on the morphology and taxonomy of the group; John Dawson additionally has assisted with the provision of materials. Emily Wood and Henry Kesner, Harvard University Herbaria, provided information on, and images of, some specimens deposited at A and GH. Marlien van der Merwe gave useful comments on the paper. Ed Biffin holds an ABRS Postgraduate Scholarship from the Australian Biological Resources Study, and a Scholarship from the Australian National University; this support is gratefully acknowledged.

\section{REFERENCES}

Ashton, P.S. 1981. Myrtaceae. In: M.D. Dassanayake, A revised handbook to the flora of Ceylon 2: 403-473. Smithsonian Institution \& National Science Foundation, Washington.

Bailey, F.M. 1886. Eugenia hemilampra. A synopsis of the Queensland flora. 1st suppl.: 23. Beal, Brisbane.

Bailey, F.M. 1891. Cryptocarya graveolens. Queensland Dept. Agric., (Bot. Bull. No. 2) Bull. No. 7: 16.

Bentham, G. \& J.D. Hooker. 1865. Myrtaceae. In: Genera Plantarum 1: 690-725. Reeve \& Co., London.

Biffin, E., L.A. Craven, M.D. Crisp \& P.A. Gadek. In press a. Molecular systematics of Syzygium and allied genera (Myrtaceae): evidence from the chloroplast genome. Taxon.

Biffin, E., L.A. Craven, M.D. Crisp, P.A. Gadek \& M.A. Harrington. In press b. Evolutionary relationships within Syzygium s.l. (Myrtaceae): Molecular phylogeny and new insights on morphology. Proc. Sixth Fl. Males. Symp.

Blume, C.L. 1850. Cleistocalyx. Mus. Bot. Lugd.-Bat. 1: 84, t. 56. Brill, Leiden.

Brongniart, A. \& A. Gris. 1865. Observations sur les Myrtacées sarcocarpées de la Nouvelle-Calédonie, et sur le nouveau genre Piliocalyx. Bull. Soc. Bot. France 12: 174-187.

Chantaranothai, P. \& J. Parnell. 1993. New taxa and combinations in Cleistocalyx and Syzygium (Myrtaceae) in Thailand. Kew Bull. 48: 589-610.

Chantaranothai, P. \& J. Parnell. 1994. A revision of Acmena, Cleistocalyx, Eugenia s.s. and Syzygium (Myrtaceae) in Thailand. Thai Forest Bull., Bot. 21: 1-123.

Craven, L.A. 1990. Acmena brassii. Austral. Syst. Bot. 3: 727, f.1.

Craven, L.A. 1998. Cleistocalyx fullagarii transferred to Syzygium (Myrtaceae). Muelleria 11: 95-96.

Craven, L.A. 2001. Unravelling knots or plaiting rope: What are the major taxonomic strands in Syzygium sens. lat. (Myrtaceae) and what should be done with them? In: L.G. Saw, L.S.L. Chua \& K.C. Khoo, Taxonomy: the cornerstone of biodiversity. Proc. Fourth Fl. Males. Symp.: 75-85. Inst. Pen. Perhutanan Malaysia, Kuala Lumpur.

Craven, L.A. 2003. Four new species of Syzygium (Myrtaceae) from Australia. Blumea 48: 479-488.

Craven, L.A. \& J. Matarczyk. In press. Syzygium. Flora of Australia. ABRS, Canberra.

Dawson, J.W. 1999. Myrtaceae, Myrtoideae I: Syzygium. In: P. Morat, Flore de la Nouvelle-Calédonie 23. Muséum National d'Histoire Naturelle, Paris. 
De Candolle, A.P. 1828. Myrtaceae. In: Prodromus systematis vegetabilis 3: 207-296. Treuttel \& Würtz, Paris.

De Lamarck, J.B.A.P. de Monnet. 1789. Eugenia elliptica. Encyclopédie méthodique 3: 206. Chez Panckoucke, Paris.

Diels, L. 1922. Die Myrtaceen von Papuasien. Bot. Jahrb. Syst. 57: 356-426.

Duthie, J.F. 1879. Eugenia operculata var. paniala. In: J.D. Hooker, Flora of British India 2: 489. Reeve \& Co., Brook, near Ashford.

Gaertner, J. 1788. Syzygium. Fructibus et seminibus plantarum 1: 166, t. 33. The Author, Stuttgart.

Gagnepain, F. 1918. Eugenia nouveau d'Indo-Chine. Notul. Syst. (Paris) 3: 316-336.

Greuter, W., J. McNeill, F.R. Barrie, H.M. Burdet, V. Demoulin, T.S. Filgueiras, D. Nicolson, P.C. Silva, J.E. Skog, P. Trehane, J.N. Turland \& P.M. Hawksworth. 2000. International code of botanical nomenclature (Saint Louis Code) adopted by the sixteenth International Botanical Congress, St Louis, Missouri, July-August 1999. Koeltz, Konigstein. (Regnum Vegetabile 138).

Guymer, G.P. \& B.P.M. Hyland. 1988. Acmena ingens. Muelleria 6: 437.

Harrington, M.G. \& P.A. Gadek. 2004. Molecular systematics of the Acmena alliance (Myrtaceae): phylogenetic analyses and evolutionary implications with reference to Australian taxa. Austral. Syst. Bot. 17: 63-72.

Hartley, T.G. \& L.A. Craven. 1977. A revision of the Papuasian species of Acmena (Myrtaceae). J. Arnold Arbor. 58: 325-342.

Hartley, T.G. \& L.M. Perry. 1973. A provisional key and enumeration of species of Syzygium (Myrtaceae) from Papuasia. J. Arnold Arbor. 54: 160-227.

Henderson, M.R. 1949. The genus Eugenia (Myrtaceae) in Malaya. Gard. Bull. Singapore 12: 1-293.

Hô, P.H. 1992. Myrtaceae. Cây-co Viêt-Nam (An illustrated Flora of Vietnam) 2: 41-74. The Author, Montreal.

Hyland, B.P.M. 1983. A revision of Syzygium and allied genera (Myrtaceae) in Australia. Austral. J. Bot., Suppl. 9: 1-164.

Kausel, E.M.L. 1957. Acmenosperma. Ark. Bot. 3: 609.

Kochummen, K. M. 1978. Myrtaceae. In: F. S.P. Ng, Tree Flora of Malaya 3: 169-254. Longman, Malaysia, Singapore.

Koorders, S.H. \& T. Valeton. 1899. Eugenia paucipunctata. Bull. Inst. Bot. Buitenzorg 2: 8.

Koorders, S.H. \& T. Valeton. 1900. Eugenia melanosticta. Meded. Lands Plantentuin 40: 159.

Korthals, P.W. 1847. Jambosa nitida. Ned. Kruidk. Arch. 1: 202.

Kostermans, A.J.G.H. 1981. Eugenia, Syzygium and Cleistocalyx (Myrtaceae) in Ceylon: A monographical revision. Quart. J. Taiwan Mus. 34: 117-188.

Mansfeld, R. 1935. Piliocalyx. Bull. Misc. Inform. Kew 1935: 449.

Menzies, G. 2003. 1421: the year China discovered the world. Bantam, London.

Merrill, E.D. 1906. Eugenia arcuatinervia. Philipp. J. Sci. 1, Suppl.: 104.

Merrill, E.D. 1915. Eugenia paucipunctata. Philipp. J. Sci., Bot. 10: 215.

Merrill, E.D. 1918. Eugenia cleistocalyx. Philipp. J. Sci., Bot. 13: 98.

Merrill, E.D. 1951 ('1950'). Readjustments in the nomenclature of Philippine Eugenia species. Philipp. J. Sci. 79: 351-430.

Merrill, E.D. \& L.M. Perry. 1937. Reinstatement and revision of Cleistocalyx Blume (including Acicalyptus A. Gray), a valid genus of the Myrtaceae. J. Arnold Arbor. 18: 322-343.

Merrill, E.D. \& L.M. Perry. 1938. A synopsis of Acmena DC., a valid genus of the Myrtaceae. J. Arnold Arbor. 19: 1-20.

Merrill, E.D. \& L.M. Perry. 1939. The myrtaceous genus Syzygium Gaertner in Borneo. Mem. Amer. Acad. Arts 18: 135-202.

Miquel, F.A.W. 1855. Jambosa melanosticta. Flora van Nederlandsch Indië 1: 432. Post, Amsterdam.

Moore, C. 1861. Nelitris ingens. Catalogue of the natural and industrial products of New South Wales: 48. International Exhibition Commissioners, Sydney.

Mueller, F. 1886. Eugenia baeuerlenii. Australas. J. Pharmacy 1: 199.

Mueller, F. 1892. Eugenia hedraiophylla. Victorian Naturalist 8: 198.

Niedenzu, F. 1893. Myrtaceae. In: A. Engler \& K. Prantl, Die natürlichen Pflanzenfamilien 3, 7: 57-105. Engelmann, Leipzig. 
Parnell, J. 1999. Numerical analysis of Thai members of the Eugenia-Syzygium group (Myrtaceae). Blumea 44: 351-379.

Parnell, J. \& P. Chantaranothai. 1996. Cleistocalyx nervosum var. paniala. Novon 6: 201.

Ridley, H.N. 1916. Eugenia dispansa. Trans. Linn. Soc. London, Bot. 9: 47.

Roxburgh, W. 1832. Eugenia paniala. Flora Indica ed. 2, 2: 489. Thacker \& Co, Calcutta.

Schmid, R. 1972a. A resolution of the Eugenia-Syzygium controversy (Myrtaceae). Amer. J. Bot. 59: $423-436$.

Schmid, R. 1972b. Floral anatomy of Myrtaceae 1. Syzygium. Bot. Jahrb. Syst. 92: 433-489.

Smith, A.C. 1971. Piliocalyx concinnus. Pacific Sci. 25: 496.

Smith, A.C. 1985. Myrtaceae. In: Flora Vitiensis Nova 3: 289-377. Pacific Tropical Botanical Garden, Lawai, Hawaii.

Smith, L.S. 1956. Acmena graveolens. Proc. Roy. Soc. Queensland 67: 34.

Turner, I.M. 1997a ('1996'). What should the kelat trees of Malaya be called? J. Singapore Natl. Acad. Sci. 22-24: 15-27.

Turner, I.M. 1997b ('1995'). Myrtaceae. In: A catalogue of the vascular plants of Malaya. Gard. Bull. Singapore 47: 370-389.

Turner, I.M. \& K.N. Gandhi. 2005. A correction in Cleistocalyx (Myrtaceae) Gard. Bull. Singapore 57: $25-27$.

Wallich, N. \& G. Bentham. 1831. Syzygium concinnum. Numer. List 3582. 